\title{
IMPLEMENTASI CUCI TANGAN DENGAN SABUN DALAM UPAYA PENCEGAHAN PENULARAN COVID-19 PADA MAHASISWA D3 KESEHATAN FAKULTAS MATEMATIKA DAN ILMU PENGETAHUAN ALAM UNIVERSITAS BENGKULU
}

\author{
${ }^{1}$ Yulianthi, ${ }^{2}$ Meita Fitriani \\ ${ }^{1,2}$ Universiatas Bengkulu \\ Korespondensi: yulianthi@unib.ac.id
}

\begin{abstract}
Abstrak
World Health Organization (WHO) melaporkan Sejak pandemik Covid-19 terjadi diakhir tahun 2019, dan lebih 200 negara di dunia terinfeksi penyebaran virus tersebut. Bahkan korban meninggal telah mencapai lebih dari 2.5 juta jiwa. Korban meninggal tidak hanya dialami masyarakat biasa tapi juga terjadi pada tenaga kesehatan seperti perawat, dokter, dan tenaga kesehatan lain. Salah satu cara mencegah penyebaran virus Covid-19 adalah dengan rutin mencuci tangan memakai sabun.Tujuan dari penelitian ini adalah untuk mengetahuui implementasi cuci tangan dengan sabun dalam upaya pencegahan dan pemutusan mata rantai penularan Covid 19 pada mahasiswa D3 kesehatan Fakultas Mipa Universitas Bengkulu. Jenis metode penelitian yang dipilih adalah deskriptif analisis, Sampel dalam penelitian ini adalah mahasiswa Prodi D3 Keperawatan dan D3 Kebidanan yang berjumlah 76 orang. Pengambilan sampel menggunakan teknik rhandom smpling yaitu pengambilan sampel secara acak. Hasil dari penelitian ini didapat Responden yang mencuci tangan menggunakan sabun sebesar $84,2 \%$. Responden yang memiliki prilaku cuci tangan baik sebesar 81,6 \% dan tingkat pencegahan penularan virus covid-19 100\% mahasiswa tidak tertular dengan mematuhi protokol cuci tangan yang baik dan benar. Sehingga kesimpulan dari penelitian ini adanya hubungan yang sinifikan antara frekuensi cuci tangan dengan perilaku cuci tangan tehadap upaya pencegahan penularan covid-19 pada mahasiswa D3 kesehatan fakultas MIPA Universitas Bengkulu.
\end{abstract}

Kata kunci: Implementasi, cuci tangan, covid-19

\section{Abstract}

The World Health Organization (WHO) reports that since the Covid-19 pandemic occurred at the end of 2019, more than 200 countries in the world have been infected with the spread of the virus. Even the death toll has reached more than 2.5 million people. The death toll is not only experienced by ordinary people but also occurs to health workers such as nurses, doctors, and other health workers. One way to prevent the spread of the Covid-19 virus is to wash hands regularly with soap. The purpose of this study was to determine the implementation of hand washing with soap in an effort to prevent and break the chain of transmission of Covid 19 in D3 health students, Faculty of Mathematics and Natural Sciences, Bengkulu University. The type of research method chosen is descriptive analysis, The sample in this study were D3 Nursing and D3 Midwifery students, totaling 76 people. Sampling using random sampling technique, namely random sampling. The results of this study obtained that $84.2 \%$ of respondents who wash their hands using soap. Respondents who have good 
handwashing behavior are $81.6 \%$ and the level of prevention of transmission of the Covid-19 virus is $100 \%$, students are not infected by following good and correct hand washing protocols. So the conclusion from this study is that there is a significant relationship between the frequency of hand washing and hand washing behavior towards efforts to prevent the transmission of covid-19 in D3 health students, Faculty of Mathematics and Natural Sciences, Bengkulu University.

Keywords: Implementation, hand washing, covid-19

\section{PENDAHULUAN}

Sejak pandemik Covid-19 terjadi diakhir tahun 2019, dan lebih 200 negara di dunia terinfeksi penyebaran virus tersebut. Bahkan korban meninggal telah mencapai lebih dari 2.5 juta jiwa. Korban meninggal tidak hanya dialami masyarakat biasa tapi juga terjadi pada tenaga kesehatan seperti perawat, dokter, dan tenaga kesehatan lain.

Covid 19 pertama kali terdeteksi sebagai pneumonia dengan sebab yang belum bisa diidentifikasi di Wuhan, China pada bulan Desember 2019. Corona virus adalah zoonosis atau virus yang ditularkan antara hewan dan manusia. Virus ini menyebar begitu cepat sehingga hanya dalam waktu satu bulan, tepatnya tanggal 30 Januari 2020 WHO sudah menyatakan covid 19 sebagai pandemi internasional global pandemic. Di Indonesia kasus positif covid 19 pertama kali teridentifikasi tanggal 2 Maret 2020 dan semenjak itu telah menyebar dengan sangat cepat. Sampai saat ini, belum ada vaksin untuk mencegah infeksi virus Corona atau COVID-19.

Virus Corona atau severe acute respiratory syndrome coronavirus 2 (SARS-CoV2) adalah virus yang menyerang sistem pernapasan. Penyakit karena infeksi virus ini disebut COVID-19. Virus Corona bisa menyebabkan gangguan ringan pada sistem pernapasan, infeksi paru-paru yang berat, hingga kematian. (https://www.alodokter.com/virus-corona).

Gejala awal infeksi virus Corona atau COVID-19 bisa menyerupai gejala flu, yaitu demam, pilek, batuk kering, sakit tenggorokan, dan sakit kepala. Setelah itu, gejala dapat hilang dan sembuh atau malah memberat. Penderita dengan gejala yang berat bisa mengalami demam tinggi, batuk berdahak bahkan berdarah, sesak napas, dan nyeri dada. Gejala-gejala tersebut muncul ketika tubuh bereaksi melawan virus Corona.

Secara umum, ada 3 gejala umum yang bisa menandakan seseorang terinfeksi virus Corona, yaitu:

- Demam (suhu tubuh di atas 38 derajat Celsius)

- Batuk kering

- $\quad$ Sesak napas

Ada beberapa gejala lain yang juga bisa muncul pada infeksi virus Corona meskipun lebih jarang, yaitu:

- Diare

- Sakit kepala

- Konjungtivitis

- Hilangnya kemampuan mengecap rasa atau mencium bau

- Ruam di kulit

Gejala-gejala COVID-19 ini umumnya muncul dalam waktu 2 hari sampai 2 minggu setelah penderita terpapar virus Corona.

Sampai saat ini, belum ada vaksin untuk mencegah infeksi virus Corona atau COVID-19. Oleh sebab itu, cara pencegahan yang terbaik adalah dengan menghindari faktor-faktor yang bisa menyebabkan Anda terinfeksi virus ini, yaitu:

- Terapkan physical distancing, yaitu menjaga jarak minimal 1-meter dari orang lain, dan jangan dulu ke luar rumah kecuali ada keperluan mendesak.

- Gunakan masker saat beraktivitas di tempat umum atau keramaian, termasuk saat pergi berbelanja bahan makanan. 
- Rutin mencuci tangan dengan air dan sabun atau hand sanitizer yang mengandung alkohol minimal $60 \%$, terutama setelah beraktivitas di luar rumah atau di tempat umum.

- Jangan menyentuh mata, mulut, dan hidung sebelum mencuci tangan.

- Tingkatkan daya tahan tubuh dengan pola hidup sehat, seperti mengonsumsi makanan bergizi, berolahraga secara rutin, beristirahat yang cukup, dan mencegah stres.

- Hindari kontak dengan penderita COVID-19, orang yang dicurigai positif terinfeksi virus Corona, atau orang yang sedang sakit demam, batuk, atau pilek.

- Tutup mulut dan hidung dengan tisu saat batuk atau bersin, kemudian buang tisu ke tempat sampah.

- Jaga kebersihan benda yang sering disentuh dan kebersihan lingkungan, termasuk kebersihan rumah.

Menurut WHO (2009) cuci tangan adalah suatu prosedur/ tindakan membersihkan tangan dengan menggunakan sabun dan air yang mengalir atau Hand rub dengan antiseptik (berbasis alkohol). Sedangkan menurut James (2008), mencuci tangan merupakan teknik dasar yang paling penting dalam pencegahan dan pengontrolan infeksi.

Menurut Susiati (2008), tujuan dilakukan cuci tangan yaitu untuk: a) menghilangkan mikroorganisme yang ada di tangan, b) mencegah infeksi silang (cross infection), c) menjaga kondisi steril, d) melindungi diri dan pasien dari infeksi, e) memberikan perasaan segar dan bersih. Indikasi cuci tangan atau lebih dikenal dengan five moments (lima waktu) cuci tangan menurut SPO gizi adalah: a) Sebelum masuk ke dalam area produksi dan distribusi, b) Setelah memegang bahan mentah/ kotor, c) Setelah memegang anggota tubuh, d) Sebelum dan setelah memporsikan makanan di plato/ alat saji pasien, e) Setelah keluar dari kamar mandi/ toilet.

Adapun rumusan masalah penelitian ini adalah apakah implementasi cuci tangan efektif dalam upaya pencegahan penularan COVID 19 pada mahasiswa D3 Kesehatan Fakultas Matematika dan Ilmu Pengetahuan Alam Universitas Bengkulu. Tujuan dari penelitian ini adalah untuk mengetahui efektifitas implementasi cuci tangan dengan sabun dalam upaya pencegahan dan pemutusan mata rantai penularan Covid 19 pada mahasiswa D3 kesehatan Fakultas Mipa Universitas Bengkulu. Manfaat dari hasil penelitian ini diharapkan dapat dijadikan sebagai bahan masukan dan evaluasi bagi seluruh civitas akademika D3 Kesehatan guna meningkatkan pengetahuan dan kepatuhan dalam pelaksanaan cuci tangan sebagai upaya pencegahan penularan COVID 19, penelitian ini juga diharapkan dapat menjadi referensi dan tambahan informasi bagi peneliti lain yang ingin mengembangkan penelitian ini.

\section{METODE PENELITIAN}

Penelitian ini dilakukan di D3 Ilmu Kesehatan Fakultas Matematika dan Ilmu Pengetahuan Alama Universitas Bengkulu. Sedangkan objek dalam penelitian ini adalah mahasiswa D3 Ilmu Kesehatan Fakultas Matematika dan Ilmu Ilmu Pengetahuan Alam Universitas Bengkulu. Waktu penelitian dilakukan pada bulan Oktober samapai dengan Desember 2020. Jenis metode penelitian yang dipilih adalah deskriptif analisis, adapun pengertian dari metode deskriptif analitis menurut Sugiono: 2017 adalah suatu metode yang berfungsi untuk mendeskripsikan atau memberi gambaran terhadap objek yang diteliti melalui data atau sampel yang telah terkumpul sebagaimana adanya tanpa melakukan analisis dan membuat kesimpulan yangberlakuuntuk umum.Dengan kata lain penelitian deskriptif analitis mengambil masalah atau memusatkan perhatian kepada masalah-masalah sebagaimana adanya saat penelitian dilaksanakan, hasil penelitian yang kemudian diolah dan dianalisis untuk diambil kesimpulannya. 


\section{HASIL DAN PEMBAHASAN}

Dari penelitian dan pengolahan data yang dilakukan didapat hasil:

1. Hubungan Frekuensi Cuci Tangan Terhadap Kejadian Penularan Covid-19

\section{Crosstab}

\begin{tabular}{|c|c|c|c|c|}
\hline & \begin{tabular}{|l|} 
penularan covid- \\
19
\end{tabular} & \multirow{3}{*}{\begin{tabular}{|l|} 
Total \\
\\
64
\end{tabular}} \\
\hline & & & $\begin{array}{|ll|}\text { tidak } & \text { tertular } \\
\text { covid-19 } & \\
\end{array}$ & \\
\hline \multirow{6}{*}{$\begin{array}{l}\text { frakuensi cuci } \\
\text { tangan }\end{array}$} & \multirow{3}{*}{$\begin{array}{lr}\text { cuci } & \text { tangan } \\
\text { dengan } & \text { sabun } \\
\text { selama }>20 & \text { detik } \\
\text { lebih dari } 3 \text { kali } \\
\text { sehari }\end{array}$} & Count & 64 & \\
\hline & & $\begin{array}{l}\% \text { within penularan } \\
\text { covid-19 }\end{array}$ & $84.2 \%$ & $84.2 \%$ \\
\hline & & $\%$ of Total & $84.2 \%$ & $84.2 \%$ \\
\hline & \multirow{3}{*}{$\begin{array}{l}\text { tidak cuci tangan } \\
\text { dengan } \\
\text { selama }>20 \text { detik } \\
\text { lebih dari } 3 \text { kali } \\
\text { sehari }\end{array}$} & Count & 12 & 12 \\
\hline & & $\begin{array}{l}\% \text { within penularan } \\
\text { covid-19 }\end{array}$ & $15.8 \%$ & $15.8 \%$ \\
\hline & & $\%$ of Total & $15.8 \%$ & $15.8 \%$ \\
\hline \multirow{3}{*}{\multicolumn{2}{|c|}{ Total }} & Count & 76 & 76 \\
\hline & & $\begin{array}{l}\% \text { within penularan } \\
\text { covid-19 }\end{array}$ & $100.0 \%$ & $100.0 \%$ \\
\hline & & $\%$ of Total & $100.0 \%$ & $100.0 \%$ \\
\hline
\end{tabular}

Berdasarkan hasil analisis di atas nampak adanya hubungan yang erat antara frukuensi cuci tangan dengan penularan covid-19, dimana frekuensi cuci tangan yang baik dapat mencegah penularan covid-19 hal ini di lihat dari perentasi responden yang tidak terinfeksi covid-19 mencapai $100 \%$

2. Hubungan Perilaku Cuci Tangan Terhadap Kejadian Penularan Covid-19

\begin{tabular}{|c|c|c|c|c|}
\hline \multicolumn{5}{|c|}{ prilaku cuci tangan * penularan covid-19 Crosstabulation } \\
\hline & & & $\begin{array}{l}\text { penularan covid- } \\
19\end{array}$ & Total \\
\hline & & & \begin{tabular}{|lr} 
tidak tertular \\
covid-19
\end{tabular} & \\
\hline \multirow{6}{*}{$\begin{array}{l}\text { prilaku cuci } \\
\text { tangan }\end{array}$} & \multirow{3}{*}{\begin{tabular}{|lrr} 
cuci tangan & sebelum \\
dan sesudah & makan, \\
sebelum dan & sesudah \\
praktikum & di \\
laboratorium, dll
\end{tabular}} & Count & 62 & 62 \\
\hline & & $\begin{array}{ll}\% & \text { within } \\
\text { penularan } & \text { covid- } \\
19 & \end{array}$ & $81.6 \%$ & $81.6 \%$ \\
\hline & & $\%$ of Total & $81.6 \%$ & $81.6 \%$ \\
\hline & \multirow{3}{*}{$\begin{array}{|llr|}\text { tidak cuci } & \text { tangan } \\
\text { sebelum } & \text { dan sesudah } \\
\text { makan, sebelum dan } \\
\text { sesudah praktikum di } \\
\text { laboratorium, dll }\end{array}$} & Count & 14 & 14 \\
\hline & & $\begin{array}{ll}\% & \text { within } \\
\text { penularan } & \text { covid- } \\
19 & \\
\end{array}$ & $18.4 \%$ & $18.4 \%$ \\
\hline & & $\%$ of Total & $18.4 \%$ & $18.4 \%$ \\
\hline \multirow{3}{*}{\multicolumn{2}{|c|}{ Total }} & Count & 76 & 76 \\
\hline & & $\begin{array}{ll}\% & \text { within } \\
\text { penularan } & \text { covid- } \\
19 & \end{array}$ & $100.0 \%$ & $100.0 \%$ \\
\hline & & $\%$ of Total & $100.0 \%$ & $100.0 \%$ \\
\hline
\end{tabular}

Berdasarkan hasil analisis di atas nampak adanya hubungan yang erat antara prilaku cuci tangan dengan penularan covid-19, dimana prilaku cuci tangan yang baik dapat mencegah penularan covid-19 hal ini di lihat dari perentasi responden yang tidak terinfeksi covid-19 mencapai $100 \%$.

Berdasarkan hasil analisis penerapan cuci tangan dengan frekuensi yang benar yakni mencuci tangan menggunakan sabun selama lebih dari 20 detik dan dilakukan lebih 
dari 3 kali dalam satu hari. Serta prilaku cuci tangan dimana mencuci tangan setiap sebelum dan sesudah makan, mencuci tangan sebelum dan sesudah praktikum di laboratorium, dan mencuci tangan setiap sebelum dan sesudah melakukan aktivitas di lingkungan luar, dapat berpengaruh signifikan terhapat upaya pencegahan penularan covid-19 dilingkungan kampus D3 Vokasi Kesehatan Universitas Bengkulu. Hal ini terlihat dari hasil yang diperoleh dimana angka penularan covid-19 yang tidak tertular mencapai $100 \%$.

Perilaku Hidup Bersih dan Sehat (PHBS) adalah upaya untuk memberikan pengalaman belajar atau menciptakan suatu kondisi bagi perorangan, keluarga, kelompok dan masyarakat, dengan membuka jalur komunikas, memberikan informasi dan edukasi untuk meningkatkan pengetahuan, sikap dan perilaku, sehingga membantu masyarakat mengenali dan mengatasi masalah sendiri, dalam tatanan rumah tangga, agar dapat menerapkan cara-cara hidup sehat dalam rangka menjaga, memelihara, dan meningkatkan kesehatan (Umaroh, dkk, 2016).

Salah satu bagian dari PHBS adalah mencuci tangan memakai sabun sebelum dan sesudah melakukan suatu kegiatan. Mencuci tangan yang baik adalah dengan mengikuti 7 langkah membersihkan tangan sesuai prosedur yang benar untuk membunuh kuman penyebab penyakit. Dengan mencuci tangan memakai sabun baik sebelum makan atau pun sebelum memulai pekerjaan, akan menjaga kesehatan tubuh dan mencegah penyebaran penyakit melalui kuman yang menempel di tangan (Ardriansyah, dkk, 2013).

Agar efektif, WHO (2009) telah menetapkan langkah-langkah cuci tangan pakai sabun sebagai berikut: membasahi kedua tangan dengan air mengalir, beri sabun secukupnya, menggosokan kedua telapak tangan dan punggung tangan, menggosok selasela jari kedua tangan, menggosok kedua telapak dengan jari-jari rapat, jari-jari tangan dirapatkan sambil digosok ke telapak tangan, tangan kiri ke kanan, dan sebaliknya, menggosok ibu jari secara berputar dalam genggaman tangan kanan, dan sebaliknya, menggosokkan kuku jari kanan memutar ke telapak tangan kiri, dan sebaliknya, basuh dengan air, dan mengeringkan tangan (WHO, 2009).

Mahasiswa merupakan pengguna layanan laboratirum yang aktif dan berinteraksi secara intens di dalam laboratorium sehingga sangat diperlukannya protokol kesehatan dalam penceahan penularan virus corona. Maka dari itu dilaboratorium mewajibkan mahasiswa untuk mencuci tangan sebelum dan sesudah melakukan praktikum dilaboratorium dengan cara melakukan cuci tangan 7 langkah dengan baik dan benar, melakukan cuci tangan lebih dari 3 kali sehari dengan durasi 20 menit setiap akan masuk dan keluar laboratorium, sebelum dan sesudah makan, dan setelah berinteraksi dengan lingkungan luar, sehingga dari hasil penelitian yang kami lakukan terdapat hubungan yang signifikan antara mencuci tangan dengan sabun secara baik dan benar dengan pencegah penularan covid-19. Hal ini dapat terlihat dari tabel penelitian bahwa seluruh mahasiswa yang melakukan cuci tangan dengan baik dan benar terhindar dari penularan virus corona (covid-19).

\section{KESIMPULAN}

Dari hasil analisis penelitian yang berjudul implementasi cuci tangan dengan sabun dalam upaya pencegahan penularan covid-19, dapat disimpulkan bahwa

1. Responden yang mencuci tangan menggunakan sabun selama lebih dari 20 detik sebanyak lebih dari 3 kali dalam sehari lebih besar $(84,2 \%)$ daripada yang tidak $(15,8$ $\%)$.

2. Responden yang memiliki prilaku cuci tangan baik yakni mencuci tangan setiap sebelum dan sesudah makan, cuci tangan sebelum dan sesudah praktikum di laboratoium, dan cuci tangan sebelum dan sesudah beraktifitas di lingkungan luar lebih besar $(81,6 \%)$ daripada yang tidak melakukan cuci tangan $(18,4 \%)$. 
3. Frekuensi cuci tangan yang benar yakni mencuci tangan menggunakan sabun selama lebih dari 20 detik dan dilakukan lebih dari 3 kali dalam sehari dapat mencegah penularan covid-19, hal ini terlihat dari data analisis dimana responden yang tidak tertular mencapai $100 \%$

4. Perilaku cuci tangan yang baik yaitu mencuci tangan sebelum dan sesudah makan, mencuci tangan sebelum dan sesudah praktikum di laboratorium serta mencuci tangan sebelum dan sesudah melakukan aktifitas di lingkungan luar dapat mencegah penularan covid-19, hal ini terlihat dari data analisis dimana responden yang tidak tertular mencapai $100 \%$

5. Adanya hubungan yang sinifikan antara frekuensi cuci tangan dengan perilaku cuci tangan tehadap upaya pencegahan penularan covid-19 pada mahasiswa D3 kesehatan fakultas MIPA Universitas Bengkulu.

\section{UCAPAN TERIMAKASIH}

Pada kesempatan ini penulis ingin mengucapkan ucapan terimakasih kepada prodi D3 kebidanan dan prodi D3 keperawatan yang telah memberi izin untuk peneliti melakukan penelitian, terimakasih kepada Ka. Labororatorium D3 Kebidanan dan D3 Keperawatan yang sudah memberi izin dan memfasilitasi peneliti untuk meneliti di Laboratorium tersebut, terimakasih kepada seluruh mahasiswa D3 Kebidanan dan D3 Keperawatan yang sudah sudi menjadi responden dalam penelitian ini.

\section{DAFTAR PUSTAKA}

Anies. 2006. Waspada Ancaman Penyakit Tidak Menular. Jakarta: PT.Elex Media Komputindo.

Ardiansyah, Y. dan Rahmantari, D.N. (2013). Penyuluhan Dan Praktik PHBS (Perilaku Hidup Bersih Sehat) Dalam Mewujudkan Masyarakat Desa Peduli Sehat. Universitas Islam Indonesia

Arikunto, 2012. Prosedur Penelitian Suatu Pendekatan Praktek. PT Rieneka Cipta, Jakarta

Budiarto, Eko, 2016. Metode Penelitian Kedokteran Suatu Pengantar. PT EGC, Jakarta Efendi. 2009. Manajemen Pusat Kesehatan Masyarakat. Jakarta: Salemba Medika. https://www.alodokter.com/virus-corona

https://stoppneumonia.id/informasi-tentang-virus-corona-novel-coronavirus/

James, J. 2008. Prinsip-Prinsip Sains Untuk Keperawatan (Indah Retno Wardhasi, Penerjemah). Jakarta: Erlangga.

Sudarma, Momon. 2008. Sosiologi Untuk Kesehatan. Jakarta: Salemba Medika.

Sugiyono. 2017, Metodelogi Penelitian Kualitatif, kuantitatif Dan RD. Bandung: CV Alfabeta

Sri G, widasari. Dkk. 2020. Ebook Evidence Based Practice: Penatalaksanaan Penanganan Luka Saat Pandemi COVID-19. Bogor-Jawa Barat:Wocare Publising

Umaroh AK, Hanggara HY, Choiri C. GAMBARAN PERILAKU HIDUP BERSIH DAN

SEHAT (PHBS) DI WILAYAH KERJA PUSKESMAS BULU

KABUPATEN SUKOHARJO BULAN JANUARI-MARET 2015. J

Kesehatan [Internet]. 2016; Available from: journals.ums.ac.id.

WHO. Guidelines on Hand Hygiene in Health Care. Library Cataloguing-inPublication Data; 2009 